\title{
Vapaus ja venäläinen lastenkasvatus
}

\author{
Anita Novitsky, Risto \\ Keskinen, Natalia Rodina \\ \& Ekaterina Protassova
}

Lastenkasvatuksen tavoitteet ovat kautta vuosisatojen liittyneet aina kulloiseenkin yhteiskuntaan, sen arvoihin ja ihanteisiin. Niin perheissä kuin institutionaalisissakin kasvatusympäristöissä, kuten kouluissa, lastenkodeissa ja päiväkodeissa, on tavoitteena ollut, että jokainen uusi sukupolvi kykenisi elämään aikuisuuttaan ristiriidattomasti, vallitsevan yhteiskunnallisen arvomaailman hyväksyen. Totalitaristissa hallintojärjestelmissä ei vallitsevaa yhteiskuntajärjestystä ole syytä kyseenalaistaa lastenkasvatuksessakaan, saati tavoitella yksilön vapaata ajattelua.

Venäjällä kasvatuksen tavoitteiden tarkastelu on erityisen mielenkiintoista, kun kasvatusihanteita peilaa maassa ideologisella tasolla tapahtuneisiin arvomuutoksiin vuosikymmenten tai jopa vuosisatojen saatossa. Äkilliset yhteiskunnallisen ilmapiirin, valtiopolitiikan sekä ihmisten selviytymisstrategioiden muutokset ovat vaikuttaneet venäläisen varhaiskasvatuksen ihanteisiin niin ideologisella kuin käytännön tasolla. Tässä esseessä pyrimme taustoittamaan sitä, miten lastenkasvatuksen ideologia on kehittynyt Venäjällä ja Neuvostoliitossa, ja millaisia vaikutuksia kasvatusideologisilla perinteillä on tämän päivän venäläiseen ihmiseen.

Esseessä käytämme institutionaalisista kasvuympäristöistä kunkin ajan hengen mukaisia nimityksiä. Kulloinkin käytetyt termit kuvaavat aikaa ja ajan muutosta: orpokodit ovat muuttuneet lastenkodeiksi, lastentarhoista on tullut päiväkoteja.

\section{Vapaus kasvatusfilosofian historiassa}

Yksilönvapaus on puhuttanut filosofeja ja tutkijoita antiikin ajoista saakka, mutta vasta 1800-luvun mullistukset eurooppalaisessa arvomaailmassa toivat vapauden kysymyksen lasten kasvatukseen erikoistuneisiin instituutioihin. Pariisin vallankumouksesta (v. 1848) katsotaan alkaneen ajan, jolloin absoluuttista monarkiaa, eli ihmisen elämää säätelevää 
absoluuttista määräysvaltaa ei ole - eikä lapsen elämää määrittävää absoluuttista määräysvaltaakaan pidä tavoitella.

Uuden aikakauden alku, jolloin ihmisideaali hahmotettiin vapauden, veljeyden ja tasaarvon kautta, vaikutti vapauskäsitteen esiintuloon myös Venäjällä ja Suomen suuriruhtinaskunnassa. Kasvatuksellinen vapaus oli kokeilevaa ja perustui ajatukselle siitä, että lapsi on oman elämänsä subjekti, jonka täytyy voida tehdä itsenäisiä valintoja ja toteuttaa niitä kasvaakseen hyväksi ihmiseksi. Kasvatuksellisen vapauden katsottiin olevan muun muassa vapautta sivistykseen ja oppimiseen riippumatta siitä, mihin yhteiskuntaluokkaan lapsi on syntynyt. Se oli myös vapautta tehdä valintoja jopa silloin, kun lapsen valinta on ristiriidassa aikuisen tavoitteiden kanssa.

Arvomaailman mullistus toi pedagogeille vapauden suunnitella ja toteuttaa kasvatusta Venäjällä. Venäläisen lapsipedagogiikan edelläkävijänä pidetty Konstantin Ušinski (1823-1871) puhui muun muassa lapsuudesta itseisarvoisena aikana ihmisen elämässä. Ušinskin mukaan lapsen tuli saada elää esikouluiässäkin vielä leikkien ja opetellen selviytymään omassa, jokapäiväisessä elämässään vapaana ilman aikuisuuden taakkaa. Lapsen vapauteen liittyi saumattomasti myös opettajan tai kasvattajan oikeus toimia parhaaksi katsomallaan tavalla, jos valittu tapa ei ollut jyrkässä ristiriidassa lapsen valinnanvapauden kanssa.

\section{Lastentarhat yleistyvät Venäjällä}

Yksi Venäjän ensimmäisistä lastentarhoista avattiin Pietarissa vuonna 1863. Syyskuun 27. päivä on Venäjällä nimetty varhaiskasvatuksen opettajien päiväksi kunnianosoituksena tälle Sofia Lugebilin perustamalle lastentarhalle. Ensimmäisissä lastentarhoissa painotettiin leikin ja työnteon merkitystä kaikkeen lasten toimintaan toverillisessa hengessä osallistuvan aikuisen opettajan kanssa. Vaikka lastentarhat muistuttivat kouluja lukujärjestyksineen, oppituntien ja toiminnan sisältö oli joustavaa. Lapset saivat leikkiä ja toteuttaa itseään vapaasti. Opettajan tehtävä oli tarjota lapsille erilaisia materiaaleja ja työtapoja, mutta lapset saivat työskennellä omassa tahdissaan, valita puuhansa itse ja käyttää luovuuttaan.

Ensimmäisten venäläisten lastentarhojen toiminta mukaili saksalaisen varhaiskasvatuksen ja päiväkotitoiminnan uranuurtajien, muun muassa Friedrich Fröbelin (1782-1852) periaatteita, jonka mukaan lapsi on aktiivinen olento, jonka omatoimisuutta, luovuutta ja luonnollista kehitystä tulee tukea kahlitsematta sitä aikuisen tahtoon. Venäläinen opettaja ja varhaiskasvattaja Adelaida Semjonovna Simonovitš (1844-1933), jota pidetään varhaiskasvatuksen ensimmäisinä uranuurtajina Venäjällä, toi sikäläiseen kasvatukseen käsitteen "synnyinmaantuntemus". Tällä tarkoitettiin lastentarhojen toiminnassa käytettävää kulttuurisen ohjauksen mallia, jolla lapsia valmisteltiin tulevaan kouluelämään hyödyntäen ympäristökasvatusta ja muun muassa vastuukasvatuksen menetelmiä.

Vanhempien oli aluksi vaikeaa ymmärtää vapaan kasvatuksen ja leikin tarpeellisuutta lapsille, olihan yksittäisissä kodeissa kuten yhteiskunnassa laajemminkin totuttu kunnioittamaan auktoriteetteja. Vanhemmat toivoivat lastentarhojen painottavan arkielämässä hyödyllisiä, työn tekoon ja opiskeluun ohjaavia taitoja, kuten keskittymistä. Vapaudelle ja itsenäiselle valinnalle ei heidän mielestään ollut tilaa elämän arjessa, sillä lapsilla oli runsaasti kotielämään liittyviä askareita ja välttämättömiä työtehtäviä vastuullaan. Tuohon aikaan kasvatuksen vapauden aatteita vaalivatkin lähinnä pedagogit ja tiedemiehet, eikä kyse ollut perheiden tapojen muutoksesta. 
1900-luvun ensimmäisellä vuosikymmenellä päiväkodit ja pikkulastenkoulut yleistyivät. Lastentarhojen toimintaa kehitettiin ja uusien kasvatusmenetelmien toimivuuden selvittämiseksi perustettiin pikkulasten tarhana toimineet "Settlement"- ja "Lasten työ ja lepo"-tutkimusyhteisöt. Näissä uusissa yksiköissä oli tavoitteena luoda kasvatusympäristö, jossa lapsi voisi löytää oman luovuutensa ja omatoimisuutensa erilaisten tarjolla olevien materiaalien työstämisen kautta. Vanhempien toiveita oli kuultu, joten työelämä- ja käsityötaidot olivat vahvasti läsnä lastentarhojen arjessa. Samaan aikaan Venäjän kansallisen koulutusministeriön ("Ministerstvo narodnogo prosveštšenija") käskystä perustettiin myös köyhemmälle väestönosalle tarkoitettuja lastentarhoja erityisesti tehdaspaikkakunnille mahdollistamaan naisten työssäkäynnin.

Koska vapaan kasvatuksen teoria ja tavoitteet olivat ristiriidassa käytännön elämän vaatimusten kanssa, perustivat kasvatuksellista vapautta puolustavat aktivistit, pedagogit ja teoreetikot vuonna 1908 Moskovaan lasten yhteiskasvatuksen ja opetuksen kerhon ("Moskovski kružok sovmestnogo vospitanija i obrazovanija detei"). Kerhon tavoitteena oli edistää ja kansantajuistaa vapaan kasvatuksen ideologiaa vanhemmille ja opettajille. Ideologian puhemiehenä muistetaan Venäjällä tuolloin toiminutta Konstantin Wentzeliä (1857-1947), joka muun muassa kirjoitti julkaisun valtion ja koululaitoksen eriyttämisestä sekä Deklaraation lapsen oikeuksista (1918), jossa hän korosti vapautta lapsuusiässä merkittävänä, ihmisen kasvua ja kehitystä parhaalla mahdollisella tavalla edistävänä piirteenä.

\section{Neuvostoliitto ja kasvatuksen vallankumous}

Venäjän vallankumouksen jälkeen perustettu valtiollinen koulutuskomissio ("Gosudarstvennaja komissija po prosveštšeniju") sai tehtäväkseen kehittää lastentarhojen ja esiopetuksen toimintaa siten, että naisten osallisuus työelämässä ja uuden Neuvostovaltion rakentamisessa toteutuisi maksimaalisesti. Tämä tarkoitti ennen kaikkea ympärivuorokautista lastenhoitoa tarjoavien yksiköiden perustamista. Maksuttomien lastentarhojen sijaan ja lisäksi perustettiin lukuisia lastenkoteja, joissa lapsen tuli asua vanhempien työviikon ajan. Ideologinen muutos valtiollisella tasolla yhteiskunnassa näyttäytyi voimakkaasti lastenkasvatukselle asetettavissa tavoitteissa.

Koska sanan- ja mielipiteenvapaus olivat vielä hauraalle neuvostovallalle riski, oli vain luonnollista, että lastentarhoissa alettiin korostaa valtiolle tärkeitä arvoja pyrkien minimoimaan lasten yksilöllisten valintojen ja vapaan ajattelun mahdollisuuksia. Pedagogiikkaa piti muokata sopivammaksi ja neuvostoihanteita korostavaksi. Pedagogiikassa ei käytetty termiä Uusi ihminen, mutta käytännössä puhuttiin uudenlaisen ihmisen luomisesta (ks. mm. Rajabinina 2009). Teoria vapaudesta ja yksilöllisyyttä korostavasta kasvatuksesta todettiin haitalliseksi ja tavoitteeksi asetettiin kasvatuksen yhdenmukaistaminen. Lapselle parasta olisi kasvaa yhteisössä ilman perheen rappeuttavaa, yksilöllistävää vaikutusta.

Kansallinen koulutuskomisariaatti ("Narodnyi komissariat prosveštšenija" eli NarKomPros) asetti vuonna 1921 kasvatusinstituutioille normitetut ohjeet kasvatuksen tavoitteista ja tuloksellisuudesta, kasvatusympäristöjen rakenteesta ja jopa arkkitehtuurista ja sisätilojen värivalinnoista, lapsiryhmien määrästä kussakin yksikössä ja lasten ikärakenteista ryhmissä. Ohjeistuksen ollessa varsin yksityiskohtaista, kasvattajien ja opettajien mahdollisuudet luoviin valintoihin ja vapauteen omassa työssään minimoitiin.

Lastentarhapedagogiikan perustana pidettiin edelleen lapsen aktiivisuutta, omatoimisuutta ja työntekoa, mutta nyt toiminta suunniteltiin opettajajohtoisesti, riippumatta lapsen vapaasta 
tahdosta ja omasta kiinnostuksesta. Lasten osaamista ja ajattelua alettiin ohjata systemaattisesti yhdenmukaisemmaksi. Kouluvalmiuksia harjaannutettiin luku- ja kirjoitustaitovalmiuksia opettamalla sekä ohjaamalla lapsia neuvostoyhteiskunnassa sosiaalisesti hyväksyttävään käyttäytymiseen ja yhteisvastuuseen.

1930-luvulla julkaistu Esiopetuksen Ohjelma toi antiproletaarisen ideologian vastustamisen ja kommunismiin kasvattamisen ohjelmatasoisena tavoitteena lastentarhojen ja esikoulujen tavoitteisiin. Tämä ohjelma ohjasi pedagogista työtä lastentarhoissa suuntaan, jonka tuli olla optimaalinen proletaarilapsen kehitykselle. Ohjelma oli yksityiskohtainen ja määritteli tarkasti lastentarhoissa ja muissa kasvatusympäristöissä annattavan opetuksen ja toiminnan sisällön. Kasvatuksellinen ja pedagoginen vapaus oli enää vain muisto.

Lastentarhojen arkeen kuuluvat leikit muokattiin sisällöllisesti sopiviksi, yhteiskuntapoliittisesti teemoiksi. Leikeissä korostettiin esimerkiksi Neuvostoliiton vihollisvaltioiden pahuutta, sosialististen aatteiden ylevyyttä ja länsimäisen ideologian turmiollista vaikutusta. Leluja ja leikkikaluja suunniteltiin nimenomaan tukemaan neuvostoihmisen kasvua. Leikkivälineissä kuvattiin Neuvostoliiton saavutuksia, jotta lapset käyttäisivät näitä teemoja myös leikeissään. Lasten leluvalikoimiin kuuluvat nuket vaihtuivat neuvostohahmoihin ja puna-armeijan sotilaisiin, uskonnollisuus häivytettiin kasvatusympäristöstä ja perinteiset satukirjatkin katosivat lastentarhojen kirjahyllyistä. Lastenkirjallisuuden luonne muuttui kasvatusihanteita mukailevaksi (ks. esim. Hellman 2016; Smirnova 2013). Toki lapsille luettiin edelleen, mutta nyt poliittisesti hyväksyttävää, neuvostoihanteita korostavaa kirjallisuutta. Valinnanvapaudesta eivät enää puhuneet pedagogit eivätkä vanhemmat.

1950-luvulle edetessä leikistä oli muotoutunut ideologisen kasvatuksen väline. Nyt leikki valjastettiin pedagogiseksi työkaluksi kouluvalmiuksien harjoittelua varten. Leikit sisälsivät teemoja lasten yhteistoiminnan kehittämiseksi ja lapsilta edellytettiin pedagogisesti perusteltuja, pitkäkestoisia leikkejä. Lasten tuli leikkiä eri ammatteja, kuten lentäjiä tai sotilaita. He saattoivat myös tehdä vaikkapa rakennusprojektien suunnittelua jakaen rakennus- ja suunnitteluroolit, valiten materiaalit rakenteluprojektiin ja toteuttaen sen suunnitelman mukaisesti. Lastenkasvatuksen ohjelmissa määriteltiin tarkasti pedagogisen leikin sisällöt unohtamatta kommunistista ideologiaa. Kaikki kasvatustyö tuli toteuttaa yhteisöissä ja valtion asettamien tavoitteiden toteutumista valvottiin. Lapsen harmonisen kehityksen ja kasvatuksen perustana alettiin nähdä päiväkodin ja perheen yhtenäinen näkemys neuvostokansalaisesta.

Lastentarhojen tavoitteena oli kasvattaa kommunistisen moraalin mukaan ajattelevia, reippaita, työteliäitä ja terveitä yhteiskunnan jäseniä. Kommunistisen moraalin mukaisesti kaikkien ihmisten oli ajateltava ja toimittava ennen kaikkea yhteiskunnan hyödyksi. Hyvää oli se, mikä edistää kommunismia ja suojelee sitä ja pahaksi se, mikä estää sen (mm. yksityisomistus, aatteen vastustaminen jne.) Vanhempien velvollisuudeksi jäi aatteellisen neuvostokansalaisen kasvatuksen tukeminen kyseenalaistamatta valtion ylläpitäminen kasvatusinstituutioiden toimintaa. Perheet eivät kuitenkaan eläneet samanlaista muutosta kuin kasvatusinstituutioiden kasvatusideaalit. Monissa perheisssä kasvatusihannetta noudatettiin muodollisesti, koska uhka ja pelko leimautumisesta huonoksi ja epäisänmaalliseksi vanhemmaksi oli merkittävä. (Ks. esim. Antonova 2010.)

\section{Neuvostoliiton romahdus ja kasvatuksen uudet tuulet}

Neuvostoliiton kommunistisen puolueen pääsihteeri Mihail Gorbatšovin uudistuspolitiikan myötä kasvatusinstituutioiden toimintaa alettiin tarkastel la uudella tavalla. Perestroikan ja 
glasnostin aika mahdollisti avoimemman keskustelun ja muutosten tuulet alkoivat puhaltaa myös kasvatuspolitiikassa ja -pedagogiikassa.

Neuvostoliiton hajoamisen jälkeen vuonna 1993 julkaistiin Venäjän federaation laki koulutuksesta. Lain myötä toteutettiin päiväkotikasvatuksessa joustava, moniammatilliseen työhön perustuva organisaatiouudistus. Tämä uudistus mahdollisti erilaisten päivähoitomuotojen keskittymisen vastaamaan lasten ja perheiden yksilöllisiin tarpeisiin ja toiveisiin. Päiväkodit erikoistuivat esimerkiksi lahjakkaiden lasten opetukseen tai vaikkapa kehityksessään tukea tarvitsevien lasten yksikköihin, ympärivuorokautisiin päiväkoteihin, lyhytaikaista hoitoa tarjoaviin keskuksiin tai erilaisia vaihtoehtoisia pedagogisia suuntauksia painottaviin yksikköihin.

Vuonna 2013 astui voimaan Venäjän federaation koulutuslaki. Lain vaatimusten mukaisesti kirjattiin esikouluopetuksen suuntaa-antavat opetussuunnitelmat toteutettavaksi koko liitovaltion alueella. Varhaiskasvatuksen laatua arvioidaan ja seurataan käyttäen kansainvälisesti tunnustettuja arviointimenetelmiä ja mittareita. Näitä kansallisia ja kansainvälisiä laatuindikaattoreita kehitetään jatkuvasti, joten myös käytettävät mittarit muuttuvat lähes jatkuvasti.

Myöhemmin on mahdollistettu vanhempien osallistuminen päiväkotien toiminnan kehittämiseen, suunnitteluun ja arviointiin. Samaan aikaan vanhemmille tarjotaan monialaisia, maksullisia lisäpalveluja osana lasten varhaiskasvatusta. Tällaisia ostettavia lisäpalveluja on tarjolla käytännöllisesti katsoen kaikilta varhaiskasvatuksen osa-alueilta.

Laaja kirjo erilaisia pedagogisia menetelmiä hyödyntäviä päiväkoteja kilpailee vanhempien huomiosta tarjoten varakkaiden perheiden lapsille juuri sitä, mistä vanhemmat ovat valmiita maksamaan. Valinnasta eri pedagogisten suuntausten välillä, lapsen kognitiivisten taitojen harjaannuttamisesta, harrastetoiminnasta ja taideaineista on muodostunut varakkaiden perheiden etuoikeus. Vapaus kasvatuksellisista valinnoista on palannut yhtenä vaihtoehtona venäläiseen pedagogiikkaan, mutta jäänyt valitettavasti yksinomaan varakkaiden perheiden etuoikeudeksi koska valtiollisia vaihtoehtoista pedagogiikkaa tarjoavia päiväkoteja ei juuri ole. Kasvatuksellinen vapaus on ikään kuin valjastettu markkinatalouden käyttöön. Valtiollisen varhaiskasvatuksen hallinnoissa ja käytännöissä ei liioin vapautta näy: koulutyössä korostetaan opettajajohtoista oppimista ja pitäydytään yleisluonteisissa julistuksissa lasten ja vanhempien osallisuudesta.

Nykyvenäläisten vanhempien käsityksiin lastenkasvatuksesta vaikuttaa edelleen niin aatteellinen vapaan kasvatuksen historia kuin neuvostovallan aikana vakiintunut yhdenmukaisuutta korostava marxilais-leniniläisen kasvatuksen ideologia. Siksi monien vanhempien on vaikea ymmärtää länsimaista lapsilähtöistä pedagogiikkaa, jossa lapsen luovuus, omatoimisuus, vapaa tahto ja valinnanvapaus ovat keskiössä. Nuoret vanhemmat ovat itse kasvaneet päiväkodeissa ja kouluissa, joissa yhdenmukaisuusideologiaa edelleen tavoiteltiin, auktoriteetteja ei kyseenalaistettu ja kommunistisen ideologisen kasvatuksen vaikutukset pedagogiikkaan olivat vielä voimissaan.

Neuvostoliitossa vallinnut totalitarismi ulottui kaikille yhteiskunnan aloille yli 70 vuoden ajan muokaten ihmisten ajattelua, arvomaailmaa ja käyttäytymistä. Mielenkiintoinen kysymys onkin, kuinka kauan kasvatuksellisen vapausteorian paluu päiväkotipedagogiikkaan tulee Venäjällä kestämään tai onko sen paluu edes mahdollista nyky-Venäjän valtarakenteet huomioiden.

Kuinka mitoitetaan oikeus kasvatukselliseen vapauteen, jos hinta löytyy yksityisten palveluntarjoajien hinnoittelussa? Jos vapaus on vain rikkaiden oikeus, niin onko se todellista vapautta? Monelle venäläisvanhemmalle maksullisuus on mahdollisuus tehdä haluamiaan 
valintoja. Vanhemmat eivät oivalla, että nämä valinnat eivät edistä kasvatuksellista vapautta, sillä heidän valintojaan ohjaillaan mainonnan ja markkinoinnin keinoin. Lapsen "vapaus" on vanhempien taskussa: jos haluaa valita, siitä pitää maksaa, sillä yksityinen päivähoito on kallista.

Ehkä venäläisvanhemman kasvua vapauteen saamme vielä odottaa, mutta toivoa on. Keskustelua kasvatuksen merkityksestä, lapsen kuulemisesta, leikistä ja luovuuden vapaudesta ei voi enää pysäyttää, totalitarismiin ei ole paluuta, kansainvälisyys ja globaalit yhteydet kasvatusyhteisöihin maailmalla näkyvät uutena tulemisena myös venäläisten perheiden kasvatusasenteissa ja -tavoitteissa. Kun vanhemmat alkavat vaatia päiväkoteihin yhä laadukkaampaa ei-kaupallista toimintaa kaikkien perheiden lasten eduksi, ollaan jo ylitetty ensimmäiset vapaan kasvatuksen tiellä olevat esteet. Vanhojen venäläisten pedagogien ja kasvatustieteilijöiden haamut hymisevät tyytyväisinä.

\section{Lähteet}

Antonova, Maria V. (2010), Sovetskaja sotsialnaja politika: semeino-bytovoi aspekt. 1950-1960-e gody: na materialah Leningrada. Kand. dis. Pietari: Pietarin valtion talouden ja raha-asioiden yliopisto. Corsaro, W.A. (2005), Sociology of Childhood. Thousand Oaks: Pine Forge Press.

Enqvist, K.; Hetemäki, I.; Tiilikainen, T. (toim.) (2017), Kaikki vapaudesta. Helsinki: Gaudeamus.

Hellman, Ben A.C. (2016), Skazka i byl: Istorija russkoi detskoi literatury. Moskova: Novoje literaturnoje obozrenije.

Key, E. (1909), The Century of the Child. New York.

Lazutova, M.N. (toim.) (2013), Doškolnoje obrazovanije v Moskve: vtšera, segodnja, zavtra. K 150-letiju sozdanija pervogo detskogo sada v Rossii. Moskova: Školnaja kniga.

Piskunov, A.I. (2007), Istorija pedagogiki i obrazovanija. Ot zaroždenija vospitanija v pervobytnom obštšestve do kontsa XX veka. Moskova: Sfera.

Rjabinina Natalja V.(2009), Vospitanije novogo tšeloveka v Sovetskoi Rossii (oktjabr 1917-1920-e gody). Sistema doškolnyh utšreždenij. Jaroslavl: Jaroslavlin valtionyliopisto.

Smirnova, Olga D. (2013), Detskaja literatura kak sredstvo vospitanija v doškolnyh utšreždenijah sovetskoi Rossii (SSSR) v 1917-1953 gg. Kand. dis. Veliki Novgorod: Novgorodin valtion yliopisto.

Wentzel, K.N. (1923), Teorija svobodnogo vospitanija i idealnyi detski sad. Petrograd. 